\title{
Responding to Environment Imbalance: Mitigation Strategies Confirm your share to save Earth
}

\author{
Dr. Priyanka Sharma \\ 303 Neelkanthvarni Apt., New Sama Vadodara-390008 Guj. India
}

\begin{abstract}
Environmental Imbalance and Global Warming is the greatest threat to Planet Earth. We have brought the Mother Earth to her deathbed through our advancing technology, industrial wastes, large scale deforestation, feckless exploitation of natural resources, polluting the environment, eroding the ozone layer; which have resulted in what might be irreversible climate change that will eventually destroy the planet. This study presents the strategies to mitigate the effects of global warming and climate change. The paper also attempts to provide suggestions/recommendations at individual level, to repair the damaged earth. This section of the paper focuses on useful plantation (trees) which are known for Environmental Conservation. There should be a healthy balance between environment and development.

Keywords: Environmental Imbalance, Irreversible, Mitigation Strategies, Sacrifice, Useful plantation
\end{abstract}

\section{Introduction}

To put in words of Professor George Wald-

"Three billion years of life, three million years of man like creatures,

10,000 years of civilization and then mere 200 years of industrial revolution, has brought us to the brink of disaster."

Last 50 years has been historic in terms of frequent and catastrophic changes brought about in the environmentin face of Global Warming, Deforestation, Ozone layer depletion, Desertification, prolonged Drought, intensified Floods and Cyclones- or just in one word- ENVIRONMENTAL IMBALANCE.

The diagram below would make the picture clear.

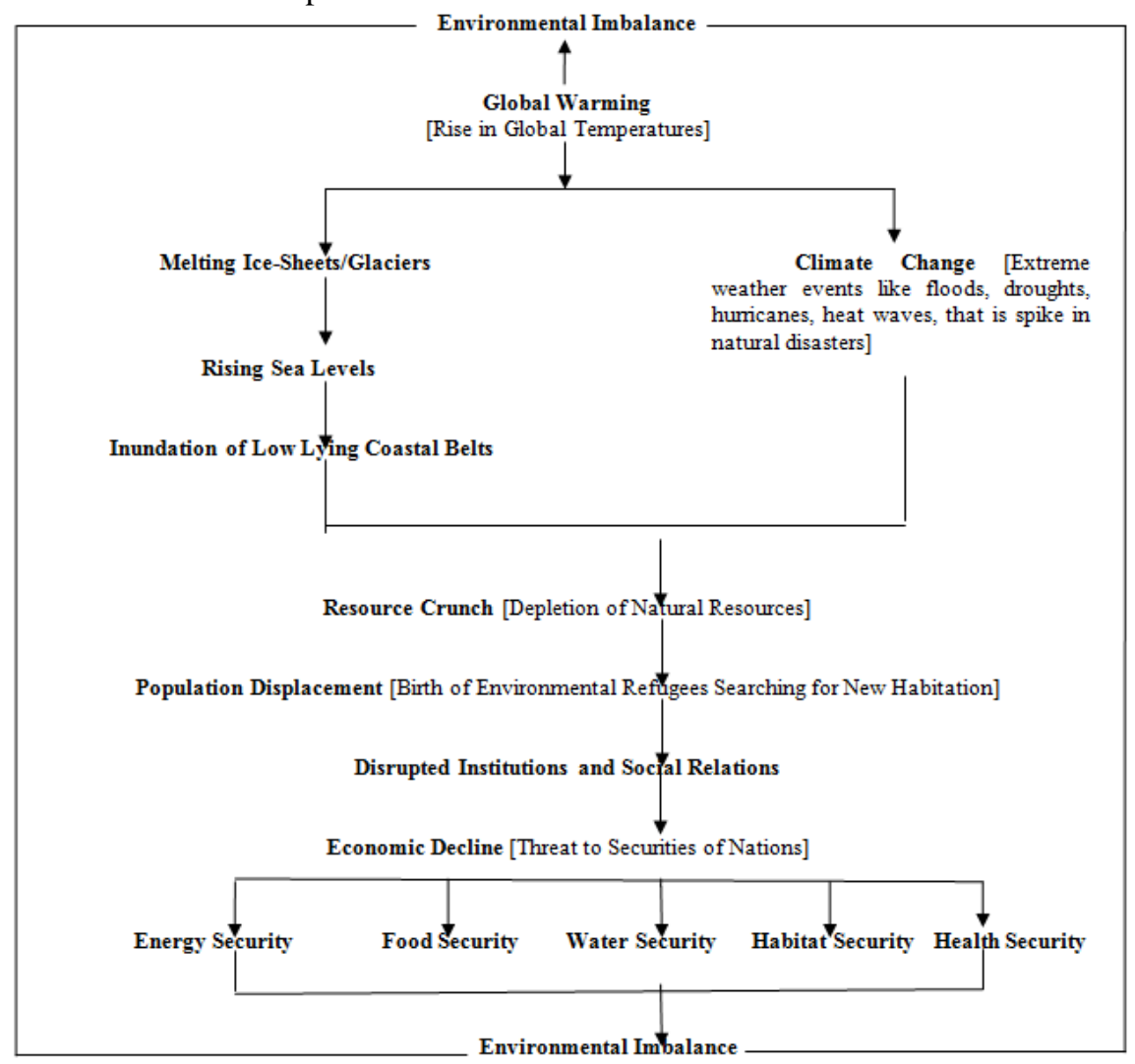


And with this, the last 42 years, since 1972 when the first serious effort to take the note of the environmental issues at the global level, has been historic in realizing and accepting the very fact that man has built a suicidal living system out of this world, that man is responsible for this environmental imbalance. The earth is stricken by a fever-that of Global Warming, and the cause of the fever is human-induced.

Here, what is important is to let people know that what should be done to mitigate the effects of global warming. I personally would like to recommend what I follow in my life and would appeal to you all to follow them for GREENER WORLD FOR BETTER WORLD. Otherwise, it is we who will perish, not the earth.

Various Conferences/meetings has been initiated with the purpose of environment protection since 1972, but the seriousness of the issue has not been felt yet. There has to be immediate cut down of green house gases and CFCs. According to the scientists, even if we stop carbon dioxide emissions now, stabilization will require several 100 years. Basically we have failed to develop common ways to protect our planet, which would have been agreed by the North (developed) and South (developing) both. We need to develop better models and gain better understanding of both climate change and variability and short-term trends in weather. We would have to soon decide how to prevent the damage to our environment. Clean Development Mechanism and Technology Transfer are some of the answers and we ought to be concerned for it. The following suggestions have been recommended at different levels to mitigate the effects of global warming and to control it.

\subsection{Responding to Environment Imbalance: Mitigation Strategies}

Striking a balance between economic development and environmental protection is essential. It has been suggested that countries ought to adopt strategies to mitigate global warming, such as energy conservation, shifting to renewable sources of energy rather than carbon fuels and thus, reduce emission of $\mathrm{CO}_{2}$ and green house gases. ${ }^{[1]}$

\subsubsection{Sacrifice}

The fact is that there is no way both to clean up the environment and conserve natural resources without changing the life style of people in the industrialized nations. The challenge is that of motivating people to make the necessary changes now, before a worldwide disaster forces much more difficult adjustments upon us. ${ }^{[2]}$

\subsubsection{Political Action}

To preserve the natural environment for ourselves and the generations to come, two things must be done. First, a stronger educational campaign must be launched to make people aware of the environmental problems. Second, more ordinary citizen must join together and become involved in the political action necessary to strengthen antipollution laws, increase the enforcement effort and protect our natural resources. ${ }^{[3]}$

\subsubsection{Conserving Resources}

There is no doubt that existing resources can be used more efficiently. It is possible that a large scale, multistage recycling program can be introduced in imitation of natural ecosystems. The immediate task is not to develop technologies that are more efficient, the challenge is to find ways of persuading people to use the conservation measures that are already available. ${ }^{[4]}$

Raising awareness on climate change may help to encourage a culture of conservation. There are many gains in terms of water and energy efficiency, that could help offset the combined impact of growing demand, population growth and climate change. ${ }^{[5]}$

\subsubsection{New Technology}

A growing number of scientists and concerned citizens are coming to see solar power as the best answer to the world's energy problems. Solar power units use the endless supply of energy from the sun, are nonpolluting and pose no threat of radiation or explosion. Such technology is an imitation of nature since all the energy in natural ecosystems ultimately comes from the sun. ${ }^{[6]}$

\subsubsection{Limiting Growth}

Any effective solution to the environmental crisis must include some form of population control, otherwise there is bound to be more and more pollution and ever increasing drain on natural resources. The world would be more peaceful and secure if the people of industrialized nations learned to accept a more leisurely life style and a lower standard of living while encouraging economic growth in the Third World. ${ }^{[7]}$

\subsubsection{Green Global Economy}

Green is not an option but a necessity for recharging the economy of the countries and creating jobs. All Governments should expand green stimulus elements including energy efficiency, renewables, mass transit, new smart electricity grids and reforestation and to co-ordinate their efforts for rapid results. Investing in the green economy is not an optional expense. It is a smart investment for a more equitable prosperous future ${ }^{\left[{ }^{8]}\right.}$

India should continue with its own climate initiatives such as solar energy project proposal and the plan to promote energy efficiency and conservation. The latter has been approved as a part of Government's National Action Plan on Climate and the Prime Minister has declared India's intention to save 5\% energy annually by 2015. ${ }^{[9]}$ We have far more effective solutions available locally like- climate-friendly diets; energy saving infrastructure, especially in buildings; terraces need to have small gardens with useful plantation, so that 
plants can work their miracle of converting $\mathrm{CO}_{2}$ into $\mathrm{O}_{2}{ }^{[10]}$ Developing countries like India have tremendous potential to improve more efficient vehicles, reduction in transmission and distribution losses, better roads and city-planning, better designed houses, they all add up to bring the cumulative change needed. ${ }^{[11]}$

\subsubsection{International Co-Operation}

International cooperation is of utmost importance to reduce planetary emissions in the wake of environmental cataclysm.

- Working out a viable financial framework to cut emissions and fund climate change mitigation strategies requires a healthy dialogue between the stake-holders.

- Innovative policies for generating renewable energy and water conservation can make climate change mitigation efforts more affordable, minimize the burden on the state exchequer and boost employment and overall growth. ${ }^{[12]}$

- Climate change and its shared security implications will be best resolved through co-operation - to reduce green-house gases emissions, to develop comprehensive international strategies to manage forced migration, to share the most innovative approaches for adaptation and to manage shared resources. ${ }^{[13]}$

\subsubsection{Green Construction Or Sustainable Building}

It is the practice of creating structure and using processes that are environmentally responsible and resourceefficient throughout a building's life-cycle. Green buildings are designed to reduce the overall impact of the built environment on human health and natural environment by efficiently using energy, water and other resources; reducing waste, pollution and environmental degradation. ${ }^{[14]}$

Better architecture and energy savings in buildings could do more to fight global warming than all curbs on GHGs. More use of concrete, metals and timber in construction and less use of energy for everything from ACs to lighting in homes and offices could save millions of dollars in a sector accounting for 30-40\% of world energy use. Switching to energy efficient light bulbs, better insulation and ventilation, avoid building a bigger house than you need. ${ }^{15]}$

\subsubsection{Organic Farming}

Promoting the production and use of organic products/food is one of the effective ways to prevent global warming. The tendency of organic soils to capture $\mathrm{CO}_{2}$ far exceeds that of the soil used in conventional farming. Estimates suggest that we can get rid of 580 billion ibs of $\mathrm{CO}_{2}$, if we resort to organic farming for food production. ${ }^{[16]}$

\subsubsection{WHO Response}

Many policies and individual choices have the potential to reduce GHGs emissions and produce major health co-benefits. For example, promoting the safe use of public transportation and active movement such as cycling and walking as alternative to using private vehicle, could reduce $\mathrm{CO}_{2}$ emissions and improve health.

In 2009, the World Health Assembly endorsed a new WHO work plan on climate change and health. This includes:

- Advocacy: to raise awareness that climate change is the fundamental threat to human health.

- Partnerships: to coordinate with partner agencies within the UN system, and ensure that health is properly represented in the climate change agenda.

- Science and evidence: to coordinate reviews of the scientific evidence on the links between climate change and health, and develop a global research agenda.

- Health system strengthening: to assist countries to assess their health vulnerabilities and build capacity to reduce health vulnerability to climate change. ${ }^{[17]}$

\subsection{Suggestions at individual level}

1.2.1 Plantation: In scientific terms, trees fix the problem of carbon emissions by absorbing them. Trees are natural air-conditioners; they are life-supporting systems. So plant a tree-nurture it, for it nurtures you.

Firstly, today what is needed is to cover one-third of the area under USEFUL PLANTATION in different sectors like- agriculture, industry, educational institutions, governmental/private organizations, residential areas, religious places, etc. I will focus on the term useful plantation- trees/plants which are eco-friendly must be planted mentioned in our VEDAS- in PANCHVATI and NAV-GRIHA VATIKA- PEEPAL, BARGAD (BANYAN TREE), NEEM, MANGO, JAMUN, MAULSHRI, GULAR, ASHOK, AONLA, BEL, must be planted. And, very importantly, trees like- EUCALYPTUS, PELTAFARM, VILAYATI BABUL (PROSOPIS JULIFLORA), AMALTASH, GULMOHAR, KASOOD, JACARANDA, etc must not be planted. For exampleprosopis juliflora has posed a serious threat to the flora and fauna of Ghana Bird Sanctuary, which has spread 
over a $20 \mathrm{~km}$ area out of $28.72 \mathrm{~km}$ Keoladeo National Park.

List of useful trees is mentioned under- ${ }^{[18]}$

Triveni Trees

\begin{tabular}{|c|c|c|c|}
\hline No. & Hindi Name & English name & Botanical name \\
\hline 1. & Neem & Neem Tree & Azadrachita indica \\
\hline 2. & Peepal & Peepal Tree, Sacred fig & Ficus religiosa Linn \\
\hline 3. & Bargad & Banyan tree & Ficus bengalensis \\
\hline
\end{tabular}

\section{Panchvati Trees}

\begin{tabular}{|c|c|c|c|}
\hline No. & Hindi Name & English name & Botanical name \\
\hline 1. & Ashok & Ashok tree & $\begin{array}{c}\text { Saraca asoca (Roxb) De wilde or } \\
\text { Saraca indica }\end{array}$ \\
\hline 2. & Bel & Bael fruit & Aegle marmelos corr. \\
\hline 3. & Aonla & Indian goose-berry & $\begin{array}{c}\text { Emblica officinalis/ Phyllanthus } \\
\text { emblica }\end{array}$ \\
\hline 4. & Peepal & Sacred fig & Ficus religiosa Linn \\
\hline 5. & Bargad & Banyan tree & Ficus bengalensis \\
\hline
\end{tabular}

Dikpala Trees

\begin{tabular}{|c|c|c|c|c|}
\hline \\
\hline No. & Direction & Hindi Name & English name & Botanical name \\
\hline 1. & North & Jamun & Jambol, Jaman & $\begin{array}{l}\text { Syzygium cumini (Linn) skeels } \\
\text { cuminum cumini }\end{array}$ \\
\hline 2. & North West & Shadar & & \\
\hline 3. & West & Kadam & $\begin{array}{l}\text { Kadamba, Common Burr } \\
\text { Flower }\end{array}$ & $\begin{array}{l}\text { Anthocephalus indicus/ Anthocephalus } \\
\text { cadamba }\end{array}$ \\
\hline 4. & South West & Chandan & Sandal wood & Santalum album \\
\hline 5. & South & Amla & $\begin{array}{c}\text { Amla, } \\
\text { Indian gooseberry }\end{array}$ & $\begin{array}{l}\text { Emblica officinalis/ } \\
\text { Phyllanthus emblica }\end{array}$ \\
\hline 6. & South East & Gular & Cluster fig & $\begin{array}{c}\text { Ficus glomerata/ } \\
\text { Ficus racemose } \\
\end{array}$ \\
\hline 7. & East & Baans & Bamboo tree & Dandrocalamus strictus \\
\hline 8. & North East & Havan & Havan Nutrush & Scleria havanensis \\
\hline
\end{tabular}

Navgraha Trees/Planet Trees/Vedic Vana

\begin{tabular}{|c|c|c|c|c|}
\hline No. & Planets & Hindi Name & English Name & Botanical name \\
\hline 1. & Sun & Madaar & Crown flower & Calotropis procera/Calotropis gigantean \\
\hline 2. & Moon & Palaash & $\begin{array}{c}\text { Jungle flame/ } \\
\text { flame of the forest }\end{array}$ & Butea monosperma (lam)/Kuntzee \\
\hline 3. & Mercury & Apamarga,Uttarini & Prickly Chaff flower & Achyranthes aspera Linn \\
\hline 4. & Mars & Kher, Kadhira & Indian Catechu & Acacia Catechue \\
\hline 5. & Jupiter & Peepal & $\begin{array}{l}\text { Peepal tree, sacred fig, } \\
\text { the holy big tree }\end{array}$ & Ficus religiosa Linn \\
\hline 6. & Venus & Gular, Oudumbara & Cluster fig, country fig & $\begin{array}{c}\text { Ficus glomerata Roxb/Ficus racemosa } \\
\text { Linn }\end{array}$ \\
\hline 7. & Saturn & Sami & Khejisi or Loong tree & $\begin{array}{c}\text { Prosopis spicgera/Prosopis cineraria } \\
\text { (L.Druce) }\end{array}$ \\
\hline 8. & Dragon's Head & Duva, Garika-gaddi & $\begin{array}{l}\text { Conchgrass, creeping } \\
\text { Dog's tooth grass, } \\
\text { Brahma grass, Doob } \\
\text { grass, debils grass }\end{array}$ & Cynodon dactylon (L) pers \\
\hline 9. & Dragon's tail & Kush, Darbha-gaddi & Halfa Grass, Thatch grass & Demostachya bipinnata Poacynosoriodis \\
\hline
\end{tabular}

\section{Rashi Trees/Zodiac Trees}

\begin{tabular}{|c|c|c|c|c|}
\hline No. & Zodiac Sign & Hindi Name & English name & Botanical name \\
\hline 1. & Aries & Laal-Chandan & Red Sandal wood & Petrocarpus santalinus Linn \\
\hline 2. & Taurus & Sapta-parni, Chitavan & $\begin{array}{c}\text { Black board tree, } \\
\text { devil tree }\end{array}$ & Alistonia scholancyn/Alistonia scularis \\
\hline 3. & Gemini & Katahal & Jack fruit & $\begin{array}{l}\text { Artocarpus integrifolia/Artocarpus } \\
\text { heterophyllus (Lamb) }\end{array}$ \\
\hline 4. & Cancer & Palaash & Forest fire & Butea monosperma (Lam) Kuntze \\
\hline 5. & Leo & Paadal, Bor & Padal Plant, Indian Plum & Stereosperum suaveolens \\
\hline 6. & Virgo & Aam & Mango & Mangifera indica Linn \\
\hline 7. & Libra & Maulshri, Vakul & Bullet wood tree & Mimusops elengi (Linn) \\
\hline 8. & Scorpio & Kher & Indian Catechu & Acacia catechue \\
\hline 9. & Sagittarius & Peepal & Sacred fig & Ficus religiosa \\
\hline 10. & Capricorn & Sheesham & Sisso & Dalbergia sissoo \\
\hline
\end{tabular}




\begin{tabular}{|c|c|c|c|c|}
\hline 11. & Aquarius & Shami & Indian Mesquite & Prosopis Cinereria \\
\hline 12. & Pisces & Bargad & Banyan tree & Ficus bengalensis \\
\hline
\end{tabular}

$\underline{\text { Nakshtra Trees/Constellation Trees }}$

\begin{tabular}{|c|c|c|c|c|}
\hline No. & Nakshatra & Hindi Name & English name & Botanical name \\
\hline 1. & Ashwini & Kuchila & Poision nut & Strychnous nux vomica \\
\hline 2. & Bharani & Aonla & Indian goose berry & Emblica officinalis \\
\hline 3. & Krittika & Gular & Cluster fig, country fig. & $\begin{array}{l}\text { Ficus glomerata Roxb/ } \\
\text { Ficus racemose Linn }\end{array}$ \\
\hline 4. & Rohini & Jamun & Jambol, Jaman Java Plum & Syzygium cumini Linn Skeels \\
\hline 5. & Mrigshira & Kher & $\begin{array}{l}\text { Kadhira, cutch tree, Indian } \\
\text { catechu }\end{array}$ & Acacia catachue \\
\hline 6. & Ardra & Seesam & Sisso & Dalbergia sissoo/ \\
\hline 7. & Punarvasu & Velu & Bamboo tree & Dendro calamus strictus \\
\hline 8. & Pushya & Peepal & Sacred fig & Ficus religiosa Linn \\
\hline 9. & Ashlesha & $\begin{array}{l}\text { Naag-Keshar/ } \\
\text { Naag-Chafa }\end{array}$ & Beauty leaf tree, wood apple & $\begin{array}{c}\text { Musa fera Linn/ } \\
\text { Mesua Musa ferrea }\end{array}$ \\
\hline 10. & Magha & Bargad & Banyan tree & Ficus bengalensis \\
\hline 11. & $\begin{array}{c}\text { Poorva } \\
\text { Phalguni }\end{array}$ & Palash & Jungle flame & Butea monosperma (lam) Kuntze \\
\hline 12. & $\begin{array}{c}\text { Uttara } \\
\text { Phalguni }\end{array}$ & Paakar & Juvvi & $\begin{array}{c}\text { Ficus bensamina/ } \\
\text { Ficus infectoria Roxb/ } \\
\text { Ficus lacor Buch }- \text { ham }\end{array}$ \\
\hline 13. & Hastha & Reetha & Soapnut tree & $\begin{array}{l}\text { Sapindus trifoliatus Linn/ } \\
\text { Sapindus mukorossi gaerta }\end{array}$ \\
\hline 14. & Chitra & Bel & Bacl, Bacl fruit tree & Aegle marmelos corr \\
\hline 15. & Swati & Arjun & Arjun tree & Termenalia arjuna Roxb \\
\hline 16. & Visakha & Katai & Katai & Flacourtia ramontchi \\
\hline 17. & Anuradha & Maulshree & Bullet wood tree & Mimusops elengi Linn \\
\hline 18. & Jyestha & Cheed & Pine & Pinus Roxburghi Sorgent \\
\hline 19. & Moola & Shaal & Sal & Shorea robusta Lamb \\
\hline 20. & Poorva-shada & Benth/Jalbetas & Cane & Arino Donex \\
\hline 21. & Uttara-shada & Kathal & Jackfruit & $\begin{array}{c}\text { Artocarpus integrifolia/ } \\
\text { Artocarpus heterophyllus (Lamb) }\end{array}$ \\
\hline 22. & Shravan & Madaar & $\begin{array}{lll}\text { Milk weed } & \text { Crown } \\
& \text { flower } & \\
\end{array}$ & $\begin{array}{c}\text { calotropis procera/ } \\
\text { calotropis gigantea lam }\end{array}$ \\
\hline 23. & Dhanishtha & Shami & Indian Mesquite, Khejri tree & $\begin{array}{c}\text { Prosopis spicgera (syn)/ } \\
\text { Prosapis cineraria L. Druce }\end{array}$ \\
\hline 24. & Shatabhishaka & Kadam & Common Bur flower & $\begin{array}{l}\text { Anthocephalus indicus/ Anthocephalus } \\
\text { cadamba }\end{array}$ \\
\hline 25. & $\begin{array}{c}\text { Poorva- } \\
\text { bhadrapada }\end{array}$ & Aam & Mango & Mangifera indica Linn \\
\hline 26. & $\begin{array}{c}\text { Uttara- } \\
\text { Bhadrapada }\end{array}$ & Neem & Neem Tree & Azadrachita indica \\
\hline 27. & Revati & Mahua & Mahua, Mohuva & $\begin{array}{c}\text { Maduca latifolia/ } \\
\text { Brassia latifolia/ } \\
\text { Madhuca indica latifolia }\end{array}$ \\
\hline
\end{tabular}

1.2.2 Secondly, go green- be vegetarian. Stop eating animals and confirm your share in maintaining ecological balance. The meat industry produces far more green house gases than the entire transport industry. A single pound of beef uses up nearly 2600 gallons of water, besides 9 pounds of food-grains, before it ends up in a meat store.

1.2.3 Thirdly, cut down on rising living standards and learn to live simple and leisurely life. The average American's lifestyle choice make him produce an unsustainable 20 tonnes of green house gases annually far exceeding the safe limit of 2.3 tonnes per head and this is the life style we are aspiring towards.

1.2.4 One single-google search produces 7 grams of carbon dioxide. Search, when it is very important, otherwise avoid it.

1.2.5 Ban the use of polythene bags, where-ever you go, like for shopping, for picnic carry a cotton/jute bag.

1.2.6 Switch on to energy efficient light bulbs, CFLs and use energy very efficiently in all walks of life.

1.2.7 Save water and electricity.

1.2.8 'Environment' as a subject must be incorporated in syllabus of schools and colleges compulsorily.

1.2.9 Communicate the importance of Nature, impact of human activities in disturbing the ecological balance, along with how to preserve it to everyone you know.

1.2.10 A silk sari destroys 50,000 silk worms. Everything that we wear, even on our feet, must be pure.

1.2.11 Environment subject must be incorporated in syllabus of schools and colleges compulsorily. 
1.2.12 Cut down private vehicles and push public transport system.

1.2.13 In terms of rules and regulations, we have the most stringent laws on books to protect the environment. But we lack in their strict enforcement. So we must join together and become involved in the political action necessary to strengthen anti-pollution laws, increase the enforcement efforts and protect our bio-diversity.

1.2.14 More importantly, we must realize that development is only possible when we act according to the laws of the environment. We cannot have one at the expense of the other.

\section{Conclusion}

The problem is what's been emitted has been emitted, although it is not fair, it's a fact that we all have to co-operate to do our utmost or we are never going to make it. Developed countries who contributed to most of the problem will have to pay for other countries to get energy access, technology and so on. Developing countries should move on with clean technologies, so that they avoid the path of dirty growth.

We have everything at our disposal, but we have to put them at right place and start working on it. We cannot progress until and unless we give the same importance to climate change and its consequences as we give to economic development or poverty alleviation and so on. Development along with environment should be our new agenda. This is the time for each and every country to revise policies that sacrifice the climate in the name of development or growth. Protection of environment and development of economy must go hand in hand.

And to put in words of Mahatma Gandhi-

"The difference between what we do and what we are capable of doing would suffice to solve most of the world's problems."

\section{References}

Mitigate Climate Change, The Times of India Ahemdabad, 19 January 2012 James Coleman ,Donald Cressey, The Environment, Social Problems, (Harper and Row Publishers, New York, 1987) 519-550 James Coleman ,Donald Cressey, The Environment, Social Problems, (Harper and Row Publishers, New York, 1987) 519-550 James Coleman ,Donald Cressey, The Environment, Social Problems, (Harper and Row Publishers, New York, 1987) 519-550 Amit Kumar Kashyap, Nikhil Warshney, and Siddharath Khare, Efforts to current policies and bring normalcy in the environment, Environmental Imbalance and Global Warming, (Gaurav Prakashan Rewa, M.P., 2010) 80-87

6] James Coleman ,Donald Cressey, The Environment, Social Problems, (Harper and Row Publishers, New York, 1987) 519-550

[7] James Coleman ,Donald Cressey, The Environment, Social Problems, (Harper and Row Publishers, New York, 1987) 519-550

[8] Banki-moon and Al Gore, Let's Go Green, The Times of India, Delhi, 21 February 2009

[9] Climate of Accord- Coordinate with Beijing to resist unfair western pressure on emissions, The Times of India, Delhi, 26 August 2009

[10] Climate is about more than just carbon emissions, The Times of India, Delhi, 28 December 2009

[11] India stresses on Kyoto standards, The Times of India, Delhi, 12 May 2007

[12] Mitigate Climate Change, The Times of India Ahemdabad, 19 January 2012

[13] Amit Kumar Kashyap, Nikhil Warshney, and Siddharath Khare, Efforts to current policies and bring normalcy in the environment, Environmental Imbalance and Global Warming, (Gaurav Prakashan Rewa, M.P., 2010) 80-87

[14] Kirti Saxena, Dr. R.K.Saxena, Impact of environmental imbalance and global warming on society-Green Building Concept: A Solution, Environmental Imbalance and Global Warming, (Gaurav Prakashan Rewa, M.P., 2010) 23-34

[15] Greener buildings can slow warming, The Times of India, Delhi, 30 March 2007

[16] Dr. Aruna Kusumakar, An analytical study of global warming and its effects, Environmental Imbalance and Global Warming, (Gaurav Prakashan Rewa, M.P., 2010) 169-176

[17] Pradeep Sharma, Dr. Atindra S Tomar and Dr. Shailendra S Tomar, Impact of climate change on health in India, Climate ChangeProblems and Solutions of Increasing Temperarure, (ShreeRam Prakashan Gwalior, M.P., 2012)10-14

[18] Ramesh Bedi, Useful Forest Trees, (Raj Kamal Prakashan, New Delhi, 2004)

S.S.Srivastava, Horticulture Science, (Central Book House Sadar Bazar, Raipur, 1990)

Acharya Balkrishna, Ayurveda Jadi-Buti Rahasya, (Divya Prakashan,Haridwar, 2005)

M.M.Bharadwaj, Gunkari Jadi-Buti Aushadhiyaan,(Anand Prakashan, Delhi, 2005)

V.N.Naik, Identification of Common Indian Medicinal Plants, (Scientific Publishers, Jodhpur Rajasthan, 2004) 